\title{
Effects of endothelin-1 on release of adrenomedullin and C-type natriuretic peptide from individual human vascular endothelial cells
}

\author{
J J Evans, A H Youssef, T G Yandle ${ }^{1}$, L K Lewis ${ }^{1}$ \\ and $\mathbf{M}$ G Nicholls ${ }^{\mathbf{3}}$ \\ University Department of Obstetrics and Gynaecology, Christchurch School of Medicine and Health Sciences, Christchurch Women's Hospital, \\ Private Bag 4711, Christchurch, New Zealand \\ ${ }^{1}$ Department of Medicine, Christchurch School of Medicine and Health Sciences, Christchurch Hospital, Riccarton Avenue, PO Box 4345, Christchurch, New Zealand \\ (Requests for offprints should be addressed to J J Evans; Email: john.evans@chmeds.ac.nz)
}

\begin{abstract}
Regulation of cardiovascular system activity involves complex interactions amongst numerous factors. Three of these vasoactive factors are adrenomedullin, C-type natriuretic peptide (CNP) and endothelin-1 (ET-1), each of which is claimed to have important local effects. To investigate paracrine/autocrine regulation of the secretion of these peptides we used a cell immunoblot method. We postulated that basal release of adrenomedullin and CNP by endothelial cells is modulated by ET-1. Dispersed human aortic endothelial cells were attached to a protein binding membrane and incubated for 1 or $4 \mathrm{~h}$ with control medium or with ET-1, endothelin receptor antagonists or antibody to ET-1, and then submitted to immunohistochemical staining. Peptides (adrenomedullin, CNP and ET-1) within individual cells were stained, as was peptide secreted and adjacent to the cell. It was demonstrated that adrenomedullin, CNP and ET-1 can be contained within
\end{abstract}

the same cell. In addition, we observed that individual endothelial cells can secrete all three peptides.

The endothelin ET-A/ET-B receptor antagonist, bosentan, the ET-B receptor antagonist, BQ-788, and anti-ET-1 serum decreased the percentage of endothelial cells that secreted adrenomedullin and CNP relative to control. Conversely, the addition of ET-1 induced an increase in the number of endothelial cells that secreted adrenomedullin and CNP. These results provide strong evidence that endogenous ET-1, from human vascular endothelial cells, acts in a paracrine/autocrine manner to modulate the basal release of adrenomedullin and CNP. Our observations of this modulation suggest that vascular endothelial cells of humans constitute an important component of a self-responsive vasoregulatory system.

Journal of Endocrinology (2002) 175, 225-232

\section{Introduction}

There is increasing evidence that regulation of cardiovascular system activity is very complex. Apart from the sympathetic nervous system and classical hormone systems, the cells of blood vessels are now known to contain a number of vasoactive peptides. These peptides, contained within vascular smooth muscle cells (VSMCs) and vascular endothelial cells, are believed to act in a local autocrine/ paracrine manner. Three such peptides, adrenomedullin, C-type natriuretic peptide (CNP) and endothelin-1 (ET-1), are synthesised within endothelial cells (Suga et al. 1993, Sugo et al. 1994a, Day et al. 1995, Harrison et al. 1995, Ishihara et al. 1997).

Adrenomedullin has vasorelaxant properties in animal models (Champion et al. 1997) and in humans (Cockcroft et al. 1997, Lainchbury et al. 2000, Troughton et al. 2000). CNP also has vasodilator properties, but its precise role under physiological and pathophysiological circumstances remains ill defined (Espiner et al. 1995). Plasma concentrations of the potent vasoconstrictor peptide, ET-1, are increased in a number of cardiovascular disorders (Cody et al. 1992, Rodeheffer et al. 1992, Tomoda 1993), implying an important role in pathophysiological conditions.

It is possible that circulating concentrations of these three peptides elicit biological responses at sites distinct from their source of production (classical hormone functioning), but there have been suggestions that they have a more important effect locally, through paracrine or autocrine processes (Suga et al. 1993, Sugo et al. 1994b, Ishihara et al. 1997, Pham et al. 1997). However, regulation of their secretion and their roles in vasoregulation remain to be characterised in detail. In this study we investigated interactions between peptides from endothelial cells. We used the cell immunoblot method (Kendall \& Hymer 1987, Arita 1993, Evans et al. 1999, Kusaka et al. 2000), which is ideally suited to investigating 
how endothelial cells within a population alter their secretory activity. Our hypothesis was that ET-1, produced within human endothelial cells, could alter the release of adrenomedullin and CNP from these same cells.

\section{Materials and Methods}

Human aortic endothelial cells (BioWhittaker, Inc., Walkersville, MD, USA) were kept as frozen aliquots at $-196{ }^{\circ} \mathrm{C}$. Aliquots were thawed and incubated in the supplier's medium at $37^{\circ} \mathrm{C}$ and subcultured twice until there was a confluent layer. Cells were then harvested and transferred to the collection medium (DMEM containing $0 \cdot 1 \% \mathrm{BSA})$ at a concentration of $6 \cdot 0 \times 10^{4}$ cells $/ \mathrm{ml}$. Cells were usually used at passages $7-9$.

Immobilon P (Millipore Corporation, Bedford, MA, USA), a polyvinylidene fluoride protein-binding hydrophobic membrane with an open pore structure that permits molecular access to bound proteins, was cut into strips, immersed in methanol for $20 \mathrm{~s}$, and allowed to dry. Glass incubation cylinders (cloning rings), of internal diameter $5 \mathrm{~mm}$ and height $90 \mathrm{~mm}$, were sealed to the membrane using silicon grease and the unit (a strip of three cylinders) was transferred to humidified six-well culture dishes (well diameter $35 \mathrm{~cm}$ ). The membrane within each cylinder was incubated with $100 \mathrm{ml}$ Dulbecco's modified Eagle's medium (DMEM) for $15 \mathrm{~min}$ and the medium aspirated off. An aliquot of cells $\left(6 \times 10^{3}\right.$ in $100 \mu \mathrm{l}$ DMEM) was then added and allowed to settle in the humidified chambers at $37^{\circ} \mathrm{C}$ for $60 \mathrm{~min}$. The viability of the cells was determined, using trypan blue, to be greater than $95 \%$. The supernatant was removed and discarded.

Medium only (DMEM) or medium containing test agent was added. In this study, ET-1 (Sigma Aldrich) in concentrations of $0.8 \mathrm{pM}$ to $80 \mathrm{nM}$, bosentan (an endothelin ET-A/ET-B receptor antagonist) $20 \mathrm{pM}$ to $2 \mu \mathrm{M}, \mathrm{BQ}-788$ (an ET-B receptor antagonist; Peninsula Laboratories, Belmont, CA, USA) $0.15 \mathrm{nM}$ to $1.5 \mu \mathrm{M}$, anti-ET serum (Peninsula Laboratories) at 1/500 dilution, gonadotrophin-releasing hormone $(\mathrm{GnRH}$; a peptide of the hypothalamo-gonadotroph axis, used in this study as a control peptide; Sigma Aldrich) $10 \mathrm{nM}$ and $100 \mathrm{nM}$, and rat luteinising hormone ( $\mathrm{LH}$; a glycoprotein produced by gonadotrophs, used in this study as a control protein; The National Hormone Pituitary Program) $1 \mathrm{ng} / \mathrm{ml}$ and $10 \mathrm{ng} / \mathrm{ml}$, were added. The cells were incubated at $37^{\circ} \mathrm{C}$ for $1 \mathrm{~h}$ or $4 \mathrm{~h}$, after which time the supernatant was removed.

Glutaraldehyde $100 \mu \mathrm{l}, \quad 2 \cdot 5 \%$ v/v (EM grade, ProSciTech, Thuringowa Central, Queensland, Australia) was added for $1 \mathrm{~h}$ at room temperature. The cells were washed three times $(10 \mathrm{~min}$ each) in $100 \mu \mathrm{l}$ Tris-HCl buffer $(100 \mathrm{mM}, \mathrm{pH}$ 8.2). Blocking buffer (Tris- $\mathrm{HCl}$ buffer containing 3\% BSA) was added for $1 \mathrm{~h}$, followed by $100 \mu \mathrm{l}$ primary antibody (in Tris- $\mathrm{HCl}$ containing $0 \cdot 3 \%$
BSA). Rabbit anti-adrenomedullin (Lewis et al. 1998) was used at 1/3000 dilution, and rabbit anti-CNP (Peninsula Laboratories) at 1/3000 dilution. The cells were incubated overnight at $4{ }^{\circ} \mathrm{C}$, then washed three times in phosphate buffer (pH 7.4) containing $0.3 \mathrm{M} \mathrm{NaCl}$ (PBS). Secondary antibody coupled to biotin (in PBS) was added at 1/1000 dilution (anti-rabbit-IgG-biotin, Sigma Aldrich) for $1 \mathrm{~h}$ and the cells and membranes washed three times in PBS. The proteins were visualised using Vectorstain kit reagents (Vector Laboratories, Burlingame, CA, USA) according to the manufacturer's instructions. Adrenomedullin was visualised using alkaline phosphatase, which produces Vector Red product, and CNP using 5-bromo-4-chloro-3-indoyl phosphate/nitro blue tetrazolium, which produces a blue product.

The glass incubation cylinders were removed from the membrane strips and the cells counterstained with Light Green CI42095 1\% in water (a general cytoplasmic stain; Gurr, Product number 34204) after the membranes had been passed through 70\% ethanol, 100\% ethanol and xylene. The cells were dehydrated in increasing concentrations of ethanol, cleared in xylene and permanently mounted. Cells were manually counted into the following categories by a single observer blinded to the experimental procedure: (a) neither containing nor secreting peptide (i.e. adrenomedullin or CNP), (b) containing but not secreting peptide, or (c) secreting (in addition to containing) peptide. The total number of immunopositive cells was obtained by adding categories (b) and (c). Approximately 225 cells were counted in each incubation cylinder, and percentages in each group were calculated.

For triple staining, cells were sequentially exposed to primary and secondary antibodies for localising adrenomedullin and CNP as described above, and to guineapig anti-ET-1 serum (Peninsula Laboratories) at 1/1000 dilution. ET-1 was localised using anti-guineapig-IgG-biotin (Sigma Aldrich), followed by Vectorstain kits using horseradish peroxidase and diaminobenzidine, which produces a brown product. Cells that were stained to localise the three peptides were not counterstained. These cells were not counted for quantitation of non-secreting and secreting cells.

Control membranes were subjected to the staining procedures in the absence of primary antisera or secondary antisera, or with replacement of primary antisera by non-immune sera or sera preadsorbed with peptide to confirm specificity of the methods. Stimulation control incubations were performed using two proteins not known to be associated with vascular modulation, GnRH, a 10 amino acid peptide and LH, a large (molecular weight approximately 30000) glycoprotein. These incubations were performed in order to control for non-specific effects induced by the factors used in this study. GnRH was added to cells at $10 \mathrm{nM}$ and $100 \mathrm{nM}$ and $\mathrm{LH}$ at $1 \mathrm{ng} / \mathrm{ml}$ and $10 \mathrm{ng} / \mathrm{ml}$. In no case was there any difference between the profiles of the cells stained for 
adrenomedullin or CNP and those seen in control incubations.

\section{Statistical analysis}

Results were analysed by one-way analysis of variance, paired $t$-test or signed rank test, and $P<0 \cdot 05$ was taken to indicate a significant difference between groups. Each experiment was carried out in duplicate or, more usually, in triplicate on at least three or, occasionally, two separate cell preparations. The replicates $(n=\mathrm{r}, \mathrm{s})$ are documented as number of incubated aliquots (r), and number of separate cell preparations (s). For statistical testing, the degrees of freedom were taken from the numbers of independent experiments, and the S.E.M.S were calculated taking the averages from incubations in an experiment as one datum value.

\section{Results}

Localisation of vasoactive peptides in human aortic endothelial cells

Cells were transferred to the membranes and subjected to the cell immunoblot procedure. Secreted peptide was visualised as stained areas around cells (Fig. 1A-F). The staining was not evenly distributed, raising the possibility that some areas of the cell membrane may have distinct functional secretory characteristics. By concurrent staining to localise adrenomedullin, CNP and ET-1 (Fig. 1G), it was demonstrated that some endothelial cells contained all three vasoactive peptides within the same cell. In addition, it was observed that some individual cells could secrete all three peptides (not illustrated).

When control incubations were examined after $4 \mathrm{~h}$, $16 \cdot 1 \pm 1 \cdot 2 \%$ of the cells were observed to have secreted adrenomedullin and another $77 \cdot 5 \pm 1 \cdot 8 \%$ of cells stained for adrenomedullin but showed no evidence of secretion that is, they were classified as adrenomedullin-containing, non-secreting cells. In control incubations, for CNP, $16 \cdot 7 \pm 0.4 \%$ of cells secreted the peptide and a further $76.9 \pm 0.9 \%$ cells contained CNP but were not observed to secrete the peptide.

\section{Modulation of adrenomedullin and CNP secretion by an $E T-A / E T-B$ receptor antagonist}

The ET-A/ET-B receptor antagonist, bosentan, decreased the proportion of cells that secreted adrenomedullin in a concentration-dependent manner after $4 \mathrm{~h}$ (Fig. 2). These effects of bosentan were also evident by $1 \mathrm{~h}$ : bosentan $20 \mathrm{nM}$ and $2 \mu \mathrm{M}$ decreased the number of secreting cells to $74 \cdot 6 \pm 2 \cdot 4 \%(n=9,3)(P<0 \cdot 01)$ and $59 \cdot 6 \pm 4 \cdot 4 \%(n=6$, 2) $(P<0 \cdot 001)$ of control respectively. Likewise, bosentan decreased the proportion of cells that secreted CNP
(Fig. 3). There were increases in the numbers of cells that contained but did not secrete adrenomedullin $(P<0 \cdot 05$ for bosentan $2 \mu \mathrm{M})$ or CNP $(P<0 \cdot 01$ for bosentan $2 \mu \mathrm{M})$.

\section{Modulation of adrenomedullin and CNP secretion by ET-1}

Endothelin-1 increased the proportion of adrenomedullinsecreting cells in a concentration-dependent manner at $4 \mathrm{~h}$ (Fig. 4). These effects were also observed at $1 \mathrm{~h}$. Endothelin-1 80 pM increased the numbers of cells secreting adrenomedullin by $127 \cdot 9 \pm 5 \cdot 8 \%(n=9,3)$ over control $(P<0 \cdot 001)$, and ET-1 $80 \mathrm{nM}$ increased the number of secreting cells by $149 \cdot 3 \pm 14 \cdot 0 \%(n=15,5)$ over control $(P<0 \cdot 01)$ at $1 \mathrm{~h}$. Exposure to ET -1 for $4 \mathrm{~h}$ also significantly increased the proportion of CNP-secreting cells (Fig. 5), and decreased the cells that contained but did not secrete CNP $(P<0 \cdot 01$ for ET-1 $80 \mathrm{nM})$.

\section{Bosentan and ET-1 together}

Bosentan, added together with ET-1, inhibited the effect of ET-1 on both the number of cells that secreted adrenomedullin and the number that secreted CNP (Tables 1 and 2).

\section{Effect of an ET-B receptor antagonist}

BQ-788, a selective ET-B receptor antagonist, reduced adrenomedullin secretion in a concentration-related manner (Fig. 6), and caused increases in the numbers of cells that contained adrenomedullin but had no detectable secretion $(P<0 \cdot 05$ with BQ-788 $1.5 \mu \mathrm{M})$.

\section{BQ-788 and ET-1 added together}

The ability of the selective ET-B receptor antagonist, BQ-788, to inhibit the action of ET-1 was also tested by adding the agents together to the cells. The enhancing effect of ET-1 on the number of cells secreting adrenomedullin was inhibited by BQ-788 (Table 1).

\section{Antiserum}

Endothelin-1 antiserum at a dilution of 1/500 reduced the numbers of cells secreting adrenomedullin or CNP, to $22 \cdot 3 \pm 6 \cdot 6 \%$ of control $(n=9,3) \quad(P<0 \cdot 01)$ for adrenomedullin-secreting cells, and $50 \cdot 3 \pm 0 \cdot 6 \%$ of control $(n=6,2)(P<0 \cdot 01)$ for CNP-secreting cells.

\section{'Used' media}

Using a slightly modified procedure, bosentan was pipetted into the medium already present, rather than into medium that was changed after $1 \mathrm{~h}$. Under these conditions, bosentan was ineffective in reducing the number 

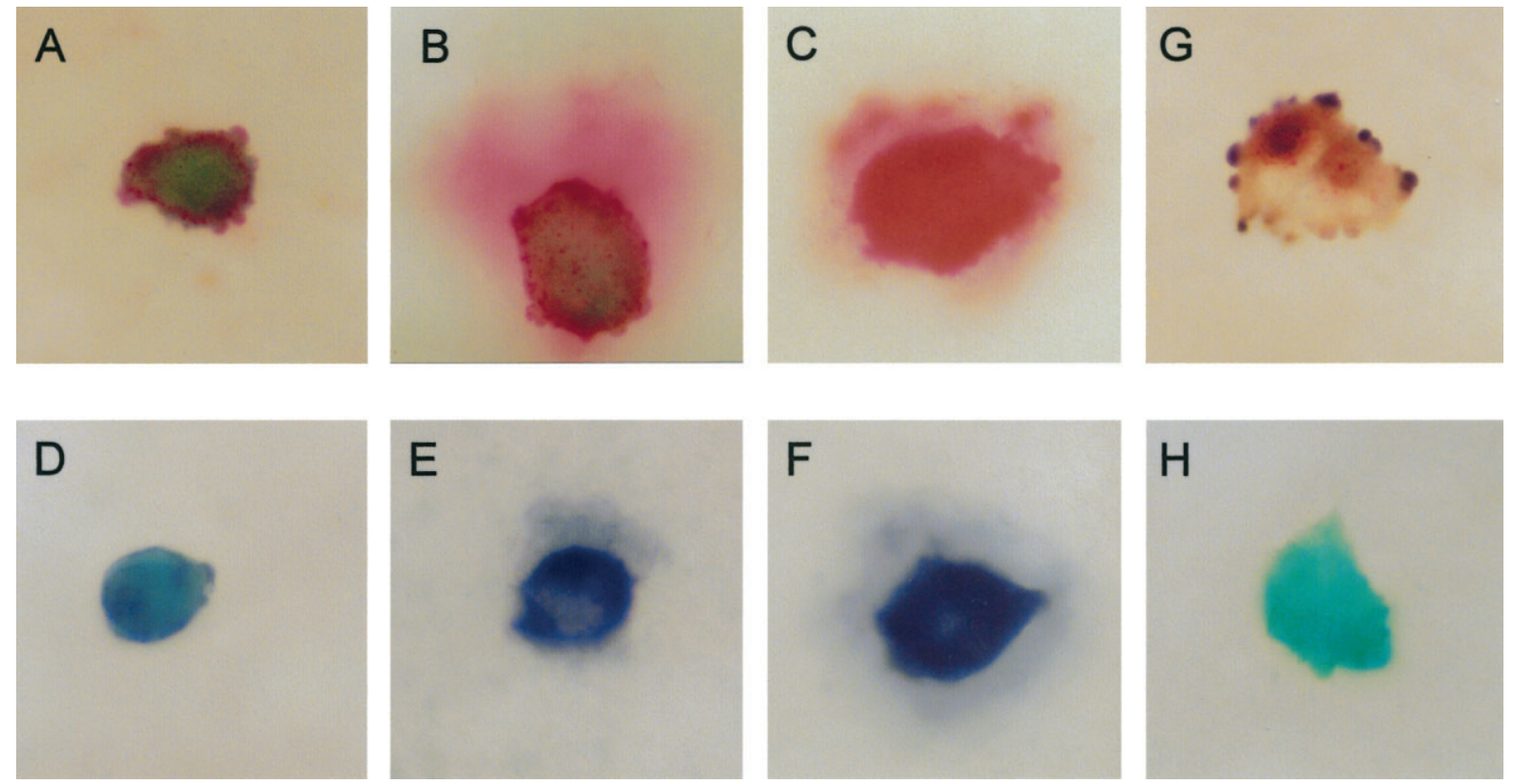

Figure 1 (A-C) Human endothelial cells that were immunopositive for adrenomedullin (red). These cells were submitted to a single-stain procedure - that is, they were exposed to anti-adrenomedullin during the immunohistochemical staining procedure, but not to other anti-peptide sera. They were counterstained with Light Green. There was a variation in intensity of staining exhibited by the cells within the cell population. Also, some cells stained for peptide but no secretion was detected (A), and some cells secreted peptide, which was indicated by the stained area outside the cell $(B, C)$. (D-F) Human endothelial cells that were immunopositive for CNP (blue). These cells were submitted to a single-stain procedure, and counterstained with Light Green. There was a variation in intensity of staining exhibited by the cells within the cell population. Also, some cells stained for peptide but no secretion was detected (D), and some cells secreted peptide, which was indicated by the stained area outside the cell (E,F). (G) A human endothelial cell that was immunopositive for all three antigens: red, adrenomedullin; blue, CNP; brown, ET-1. The cell was not counterstained. These results indicated that all three peptides could be present in an individual human endothelial cell. $(\mathrm{H}) \mathrm{A}$ human endothelial cell that was counterstained with Light Green and did not stain immunohistochemically for vasoactive peptide.

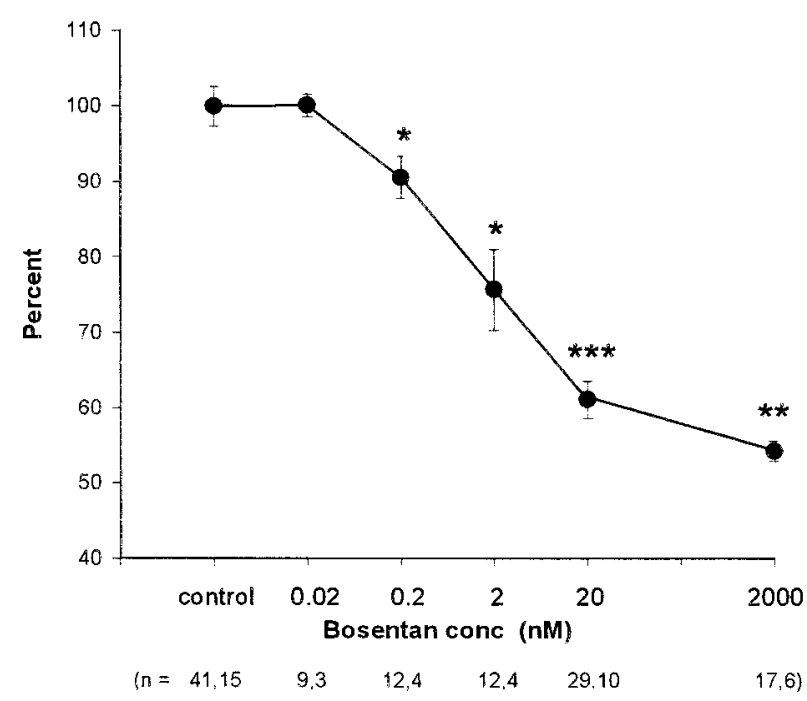

Figure 2 Percentage of human endothelial cells that secreted adrenomedullin compared with control cells after $4 \mathrm{~h}$ of incubation with bosentan. $n=$ number of incubated aliquots, number of experiments; conc, concentration. ${ }^{*} P<0 \cdot 05$; ${ }^{* *} P<0 \cdot 01$; ${ }^{* * *} P<0 \cdot 001$ compared with control. of secreting cells (Fig. 7). Similar results were obtained when the peptide BQ-788 was used.

\section{Discussion}

The cell immunoblot method has been used by us and by others to investigate cellular functioning of the pituitary (Kendall \& Hymer 1987, Arita 1993, Evans et al. 1999), and it has been applied by one group to endothelial cells (Kusaka et al. 2000). One advantage of the method is that, at the level of single cells, local secretion of peptide hormones can be detected and information can be obtained that is otherwise lost when the averaged output in supernatant media is determined using conventional cell culture methods. We now report that it is feasible to use the cell immunoblot method to investigate the interactions of three peptides, adrenomedullin, CNP and ET-1, in human aortic endothelial cells.

In our investigation, using triple staining, we were able to detect all three peptides, adrenomedullin, CNP and ET-1, in the same human endothelial cell. We also demonstrated, using the cell immunoblot method, that at 


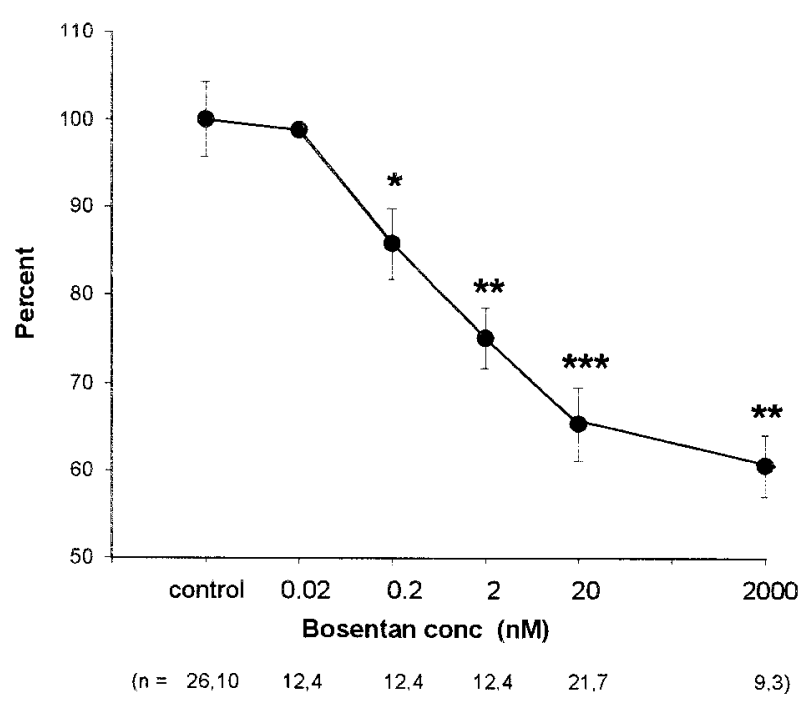

Figure 3 Percentage of human endothelial cells that secreted CNP compared with control cells after $4 \mathrm{~h}$ of incubation with bosentan. $n=$ number of incubated aliquots, number of experiments; conc, concentration. ${ }^{*} P<0 \cdot 05 ;{ }^{* *} P<0 \cdot 01 ;{ }^{* *} P<0 \cdot 001$ compared with control.

least some cells secreted the three peptides. However, because of possible masking effects by multiple stain deposits, we could not reliably establish the absence of a peptide from cells that exhibited staining for other peptides, and so quantitation of subpopulations by multiple staining was not possible. An earlier study suggested that virtually all endothelial cells derived from coronary arteries secreted both ET-1 and angiotensin II (Kusaka et al. 2000). Our results are more in concert with those of another investigation (Fischer et al. 1997), which observed that only a fraction of cells that contained angiotensin II also secreted the peptide.

Only ET-B receptors have been identified in endothelial cells, although both ET-A and ET-B receptors have been observed in VSMCs. Hence, in the present study, the ET-A/ET-B receptor antagonist, bosentan, was presumably acting to reduce adrenomedullin and CNP via ET-B receptors. Indeed, this was confirmed by using an ET-B receptor antagonist, BQ-788. To investigate whether the cells were in fact responsive to ET-1, the peptide was added to the incubations and found to increase the numbers of cells that secreted adrenomedullin and CNP in a concentration-dependent manner. Thus there seems no doubt that ET-1, acting via ET-B receptors, can modulate adrenomedullin and CNP secretion from human endothelial cells. That ET-1 is secreted into the extracellular spaces before its binding to the ET-B receptor is suggested by the inhibitory effect of ET-1 antiserum on adrenomedullin and CNP secretion. Although other groups (Schiffrin 1999, Giardina et al. 2001) have inferred that endothelin induces release of

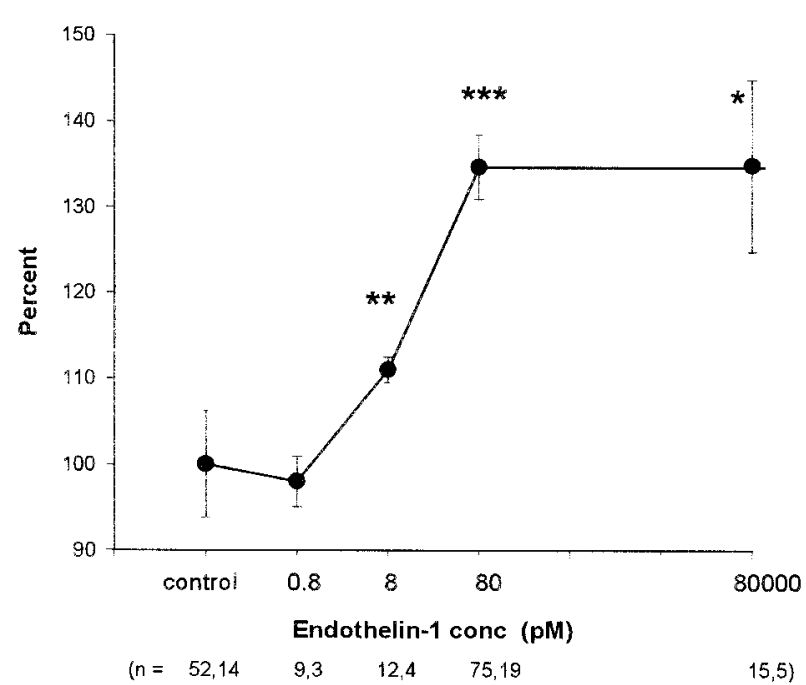

Figure 4 Percentage of human endothelial cells that secreted adrenomedullin compared with control cells after $4 \mathrm{~h}$ of incubation with ET-1. $n=$ number of incubated aliquots, number of experiments; conc, concentration. ${ }^{*} P<0 \cdot 05 ;{ }^{*} P<0 \cdot 01$; ${ }^{* * \star} P<0 \cdot 001$ compared with control.

active vasorelaxing factors (such as nitric oxide and prostacyclin) from rat endothelial cells in basal conditions, the current investigation demonstrated that ET-1 can modulate basal, tonic regulation of adrenomedullin and CNP secretion from human endothelial cells, as both ET-1 antiserum and the ET-B receptor antagonists reduced secretion of the two peptides.

Endothelin-1 has been observed in previous studies to inhibit (Isumi et al. 1998) or to increase (Jougasaki et al. 1998) the release of adrenomedullin from endothelial cells. The findings of our studies, under quite different experimental conditions, support the data of Jougasaki et al. (1998) in demonstrating stimulation of adrenomedullin secretion by ET-1, and extend those observations by also showing inhibition of adrenomedullin secretion with anti-ET-1 antiserum or receptor blockade.

Other studies have used prolonged periods $(6-24 \mathrm{~h})$ to detect increases in concentrations of peptides in supernatant media in cultures of endothelial cells (Suga et al. 1993, Isumi et al. 1998, Jougasaki et al. 1998). Under conditions utilised here, we observed responses in adrenomedullin and CNP secretion by individual cells at $4 \mathrm{~h}$, and even at $1 \mathrm{~h}$. Further studies may clarify just how rapidly these cells can respond to peptide agonists and antagonists.

Interactions between the biological effects of the three peptides studied here have been suggested previously (Chun et al. 1997, Hillier et al. 2001, Honing et al. 2001). Our study provides evidence that interactions occur at the cellular level in regard to secretion, with increasing recruitment of vasorelaxant peptide-secreting endothelial cells. Such information gathered at the level of single cells 


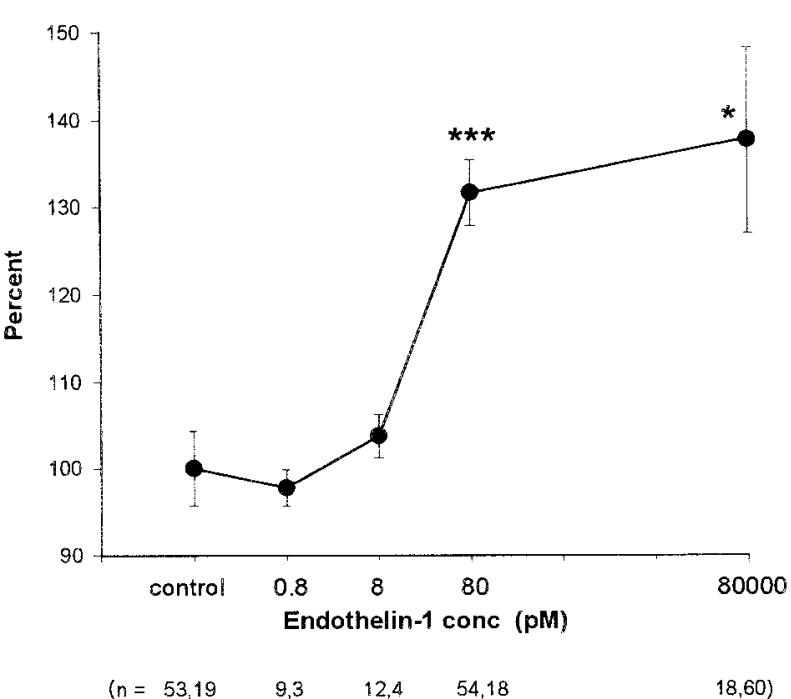

Figure 5 Percentage of human endothelial cells that secreted CNP compared with control cells after $4 \mathrm{~h}$ of incubation with ET-1. $n=$ number of incubated aliquots, number of experiments; conc, concentration. ${ }^{*} P<0 \cdot 05 ;{ }^{* * *} P<0 \cdot 001$ compared with control.

using the cell immunoblot method provides data complementary to those obtained by analysing the supernatants from classical cell culture techniques.

Relatively high concentrations of the peptides studied here might develop in the local, intercellular environment (Suga et al. 1993, Sugo et al. 1994b, Ishihara et al. 1997, Pham et al. 1997) but may be reflected poorly, if at all, by changes in their plasma concentrations or overall averaged secretion from classical cell cultures. Hence this study focused on local production by single cells. It will be an interesting challenge to determine how concentrations of peptides within or between cells relate to circulating concentrations.

The incubation conditions in our study proved critical to delineating responses in hormone secretion. 'Standard' conditions were $1 \mathrm{~h}$ of pretreatment incubation before the media were changed and antagonist/agonist were added in fresh media. However, if medium was left unchanged and bosentan or BQ788 pipetted into the 'used' media, the modulating effects of antagonists was abolished. These

Table 1 Number of human aortic endothelial cells that secreted adrenomedullin, expressed as percent of control value after $4 \mathrm{~h}$ of incubation with the active factor shown

Secreting cells (\% of control)

Endothelin-1 (80 pM)

$134 \cdot 7 \pm 3 \cdot 6$ $(n=57,19)$

Endothelin plus bosentan $(20 \mathrm{nM}) \quad 82 \cdot 0 \pm 0 \cdot 9(P<0 \cdot 05)(n=9,3)$

Endothelin plus bosentan $(2 \mu \mathrm{M}) \quad 72 \cdot 47 \pm 4 \cdot 3(P<0 \cdot 01) \quad(n=9,3)$

Endothelin plus BQ-788 $(15 \mathrm{nM}) \quad 71 \cdot 3 \pm 8 \cdot 1(P<0 \cdot 01)(n=9,3)$

The $P$ value is relative to incubation with endothelin-1. $n=$ number of incubated aliquots, number of experiments.

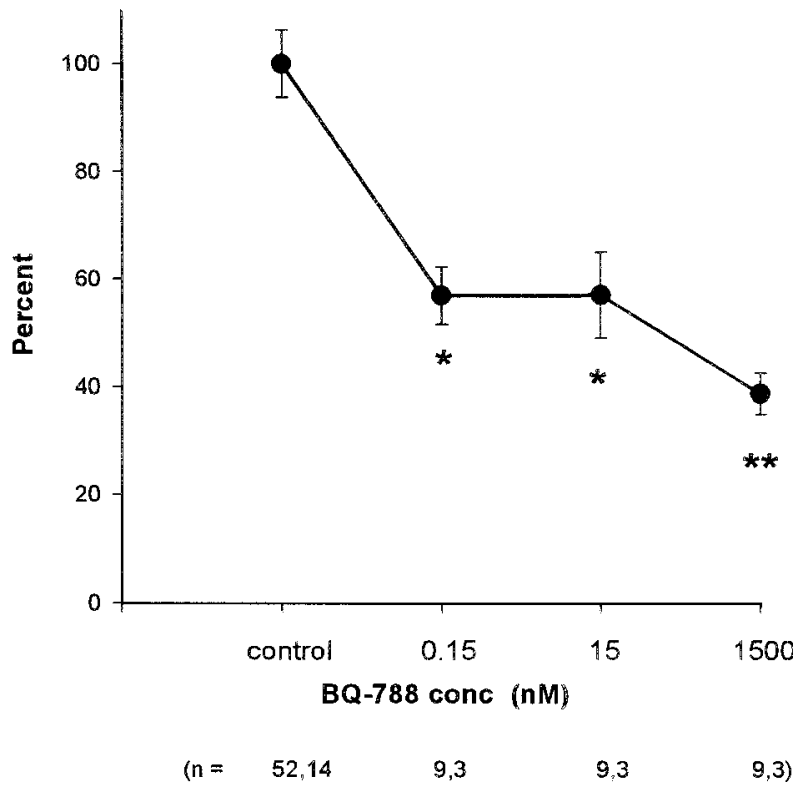

Figure 6 Percentage of human endothelial cells that secreted adrenomedullin compared with control cells after $4 \mathrm{~h}$ of incubation with BQ-788. $n=$ number of incubated aliquots, number of experiments; conc, concentration. ${ }^{\star} P<0 \cdot 05 ;{ }^{* *} P<0 \cdot 01$ compared with control.

observations suggest that, unsurprisingly, other autocrine/ paracrine factors (Suga et al. 1993, Isumi et al. 1998), besides those that were the focus of this study, are involved in vasoactive peptide regulation in endothelial cells.

In summary, we have shown, using the cell immunoblot method, that some human aortic endothelial cells have the potential to secrete all three of the vasoactive peptides, adrenomedullin, CNP and ET-1. Furthermore, ET-1 increased, in a dose-response fashion, the proportion of cells that secreted adrenomedullin and CNP, whereas bosentan, BQ-788 and anti-endothelin serum had the opposite effects. The results suggest that endogenous ET-1 modulates basal secretion of adrenomedullin and CNP in individual endothelial cells. Furthermore, our observations, along with earlier reports that secretion of endothelin can, in turn, be affected by adrenomedullin and CNP (Emori et al. 1993, Hirata et al. 1995, Kohno et al. 1995,

Table 2 Number of human aortic endothelial cells that secreted $\mathrm{CNP}$, expressed as percent of control value after $4 \mathrm{~h}$ of incubation with the active factor shown

Secreting cells (\% of control)

Endothelin-1 (80 pM)

$\overline{131 \cdot 7 \pm 3 \cdot 7 \quad(n=54,18)}$

Endothelin plus bosentan $(20 \mathrm{nM}) \quad 97 \cdot 7 \pm 4 \cdot 5(P<0 \cdot 01) \quad(n=12,4)$ Endothelin plus bosentan $(2 \mu \mathrm{M}) \quad 80 \cdot 6 \pm 4 \cdot 0(P<0 \cdot 001)(n=12,4)$

The $P$ value is relative to incubation with endothelin-1. $n=$ number of incubated aliquots, number of experiments. 


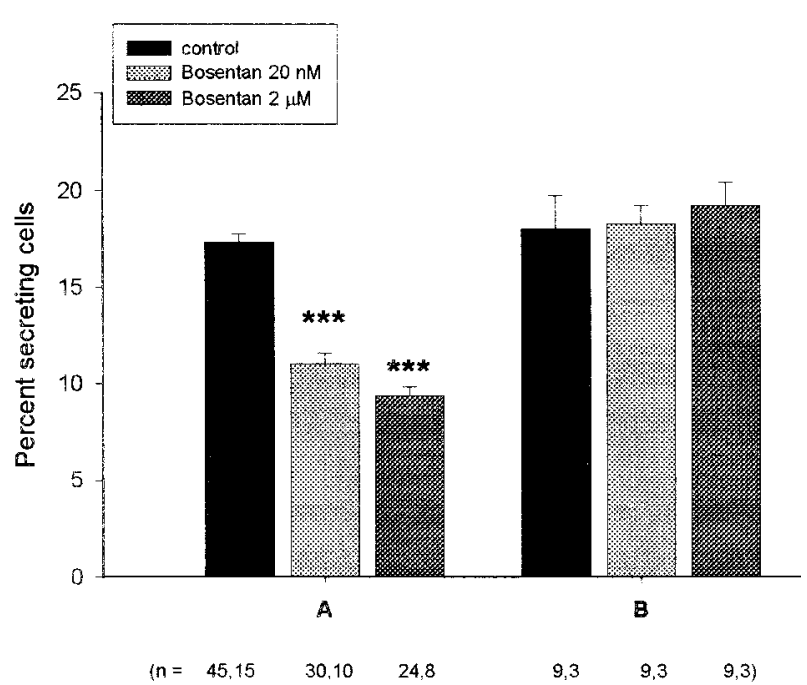

Figure 7 Percent of endothelial cells secreting adrenomedullin after $1 \mathrm{~h}$ of pretreatment incubation followed by $4 \mathrm{~h}$ incubation with bosentan. (A) The media were changed after $1 \mathrm{~h}$ and bosentan was added to the cells in fresh media. (B) The media were not changed after $1 \mathrm{~h}$ pretreatment incubation, and normal medium or medium containing bosentan was pipetted into the incubation. $n=$ number of incubated aliquots, number of experiments. ${ }^{* *} P<0 \cdot 001$ compared with control.

Miura et al. 1995, Barker \& Corder 1997, Hillier et al. 2001), and can modify the response of vasoactive peptide at the target cell (Eguchi et al. 1994, Vigne et al. 1994, Fixler et al. 2001), suggest the existence of a finely tuned, self-responsive vasoregulatory system with an important component residing within endothelial cells.

\section{Acknowledgements}

We very much appreciate the assistance of M Smith and G Roberts with the care and harvesting of the cells. We thank Dr M Rademaker for a generous gift of bosentan. We are grateful for the support of the Canterbury Medical Research Foundation and the NZ Lotteries Board during these studies

\section{References}

Arita J 1993 Analysis of the secretion from single anterior pituitary cells by cell immunoblot assay. Endocrine Journal 40 1-15.

Barker S \& Corder R 1997 Adrenomedullin acts as a local mediator of vascular homeostasis through interactions which lead to reduced endothelin-1 synthesis and secretion. Journal of Human Hypertension 11 605-606.

Champion HC, Lambert DG, McWilliams SM, Shah MK, Murphy WA, Coy DH \& Kadowitz PJ 1997 Comparison of responses to rat and human adrenomedullin in the hindlimb vascular bed of the cat. Regulatory Peptides 70 161-165.

Chun TH, Itoh H, Ogawa Y, Tamura N, Takaya K, Igaki T, Yamashita J, Doi K, Inoue M, Masatsugu K et al. 1997 Shear stress augments expression of C-type natriuretic peptide and adrenomedullin. Hypertension 29 1296-1302.

Cockcroft JR, Noon JP, Gardner-Medwin J \& Bennett T 1997 Haemodynamic effects of adrenomedullin in human resistance and capacitance vessels. British Journal of Clinical Pharmacology 44 57-60.

Cody RJ, Haas GJ, Binkley PF, Capers Q \& Kelley R 1992 Plasma endothelin correlates with the extent of pulmonary hypertension in patients with chronic congestive heart failure (Published erratum appears in Circulation 1993 87:1064). Circulation 85 504-509.

Day R, Lariviere R \& Schiffrin EL 1995 In situ hybridization shows increased endothelin-1 mRNA levels in endothelial cells of blood vessels of deoxycorticosterone acetate-salt hypertensive rats. American Journal of Hypertension 8 294-300.

Eguchi S, Hirata Y, Imai T \& Marumo F 1994 C-type natriuretic peptide upregulates vascular endothelin type $\mathrm{B}$ receptors. Hypertension 23 936-940.

Emori T, Hirata Y, Imai T, Eguchi S, Kanno K \& Marumo F 1993 Cellular mechanism of natriuretic peptides-induced inhibition of endothelin-1 biosynthesis in rat endothelial cells. Endocrinology 133 2474-2480.

Espiner EA, Richards AM, Yandle TG \& Nicholls MG 1995 Natriuretic hormones. Endocrinology and Metabolism Clinics of North America 24 481-509.

Evans JJ, Youssef AH, Abbas MM \& Schwartz J 1999 GnRH and oxytocin have nonidentical effects on the cellular LH response by gonadotrophs at pro-oestrus. Journal of Endocrinology 163 345-351.

Fischer TA, Ungureanu-Longrois D, Singh K, de Zengotita J, DeUgarte D, Alali A, Gadbut AP, Lee MA, Balligand JL, Kifor I et al. 1997 Regulation of bFGF expression and ANG II secretion in cardiac myocytes and microvascular endothelial cells. American Journal of Physiology 272 H958-H968.

Fixler R, Hasin Y, Eilam Y, Zhang DF \& Nir A 2001 Opposing effects of endothelin-1 on C-type natriuretic peptide actions in rat cardiomyocytes. European Journal of Pharmacology 423 95-98.

Giardina JB, Green GM, Rinewalt AN, Granger JP \& Khalil RA 2001 Role of endothelin B receptors in enhancing endotheliumdependent nitric oxide-mediated vascular relaxation during high salt diet. Hypertension 37 516-523.

Harrison VJ, Barnes K, Turner AJ, Wood E, Corder R \& Vane JR 1995 Identification of endothelin 1 and big endothelin 1 in secretory vesicles isolated from bovine aortic endothelial cells. PNAS 92 6344-6348.

Hillier C, Petrie MC, Love MP, Johnston F, MacLean MR \& McMurray JJ 2001 Effect of adrenomedullin on the production of endothelin-1 and on its vasoconstrictor action in resistance arteries: evidence for a receptor-specific functional interaction in patients with heart failure. Clinical Science $10145-51$.

Hirata Y, Hayakawa H, Suzuki Y, Suzuki E, Ikenouchi H, Kohmoto O, Kimura K, Kitamura K, Eto T, Kangawa K et al. 1995 Mechanisms of adrenomedullin-induced vasodilation in the rat kidney. Hypertension 25 790-795.

Honing ML, Smits P, Morrison PJ, Burnett JCJ \& Rabelink TJ 2001 C-type natriuretic peptide-induced vasodilation is dependent on hyperpolarization in human forearm resistance vessels. Hypertension 37 1179-1183.

Ishihara T, Kato J, Kitamura K, Katoh F, Fujimoto S, Kangawa K \& Eto T 1997 Production of adrenomedullin in human vascular endothelial cells. Life Sciences $601763-1769$.

Isumi Y, Shoji H, Sugo S, Tochimoto T, Yoshioka M, Kangawa K, Matsuo H \& Minamino N 1998 Regulation of adrenomedullin production in rat endothelial cells. Endocrinology $139838-846$.

Jougasaki M, Schirger JA, Simari RD \& Burnett JCJ 1998 Autocrine role for the endothelin-B receptor in the secretion of adrenomedullin. Hypertension 32 917-922.

Kendall ME \& Hymer WC 1987 Cell blotting: a new approach to quantify hormone secretion from individual rat pituitary cells. Endocrinology 121 2260-2262. 
Kohno M, Kano H, Horio T, Yokokawa K, Yasunari K \& Takeda T 1995 Inhibition of endothelin production by adrenomedullin in vascular smooth muscle cells. Hypertension 25 1185-1190.

Kusaka Y, Kelly RA, Williams GH \& Kifor I 2000 Coronary microvascular endothelial cells cosecrete angiotensin II and endothelin-1 via a regulated pathway. American Journal of Physiology 279 H1087-H1096.

Lainchbury JG, Troughton RW, Lewis LK, Yandle TG, Richards AM \& Nicholls MG 2000 Hemodynamic, hormonal, and renal effects of short-term adrenomedullin infusion in healthy volunteers. Journal of Clinical Endocrinology and Metabolism $\mathbf{8 5}$ 1016-1020.

Lewis LK, Smith MW, Yandle TG, Richards AM \& Nicholls MG 1998 Adrenomedullin(1-52) measured in human plasma by radioimmunoassay: plasma concentration, adsorption, and storage. Clinical Chemistry 44 571-577.

Miura K, Ebara T, Okumura M, Matsuura T, Kim S, Yukimura T \& Iwao H 1995 Attenuation of adrenomedullin-induced renal vasodilatation by $\mathrm{N}^{\mathrm{G}}$-nitro L-arginine but not glibenclamide. British Journal of Pharmacology 115 917-924.

Pham I, Sediame S, Maistre G, Roudot-Thoraval F, Chabrier PE, Carayon A \& Adnot S 1997 Renal and vascular effects of C-type and atrial natriuretic peptides in humans. American Journal of Physiology 273 R1457-R1464.

Rodeheffer RJ, Lerman A, Heublein DM \& Burnett JCJ 1992 Increased plasma concentrations of endothelin in congestive heart failure in humans. Mayo Clinic Proceedings 67 719-724.

Schiffrin EL 1999 State-of-the-Art lecture. Role of endothelin-1 in hypertension. Hypertension 34 876-881.
Suga S, Itoh H, Komatsu Y, Ogawa Y, Hama N, Yoshimasa T \& Nakao K 1993 Cytokine-induced C-type natriuretic peptide (CNP) secretion from vascular endothelial cells - evidence for CNP as a novel autocrine/paracrine regulator from endothelial cells. Endocrinology 133 3038-3041.

Sugo S, Minamino N, Kangawa K, Miyamoto K, Kitamura K, Sakata J, Eto T \& Matsuo H 1994a Endothelial cells actively synthesize and secrete adrenomedullin (Published erratum appears in Biochemical and Biophysical Research Communications 1994203 1363). Biochemical and Biophysical Research Communications 201 1160-1166.

Sugo S, Minamino N, Shoji H, Kangawa K, Kitamura K, Eto T \& Matsuo H $1994 b$ Production and secretion of adrenomedullin from vascular smooth muscle cells: augmented production by tumor necrosis factor-alpha. Biochemical and Biophysical Research Communications 203 719-726.

Tomoda H 1993 Plasma endothelin-1 in acute myocardial infarction with heart failure. American Heart Journal 125 667-672.

Troughton R, Lewis L, Yandle T, Richards A \& Nicholls M 2000 Hemodynamic, hormone and urinary effects of adrenomedullin infusion in essential hypertension. Hypertension 36 588-593.

Vigne P, Lund L \& Frelin C 1994 Cross talk among cyclic AMP, cyclic GMP, and $\mathrm{Ca}(2+)$-dependent intracellular signalling mechanisms in brain capillary endothelial cells. Journal of Neurochemistry 62 2269-2274.

Received 2 May 2002

Accepted 13 June 2002 